\title{
Health Expenditures and Health Outcomes in Kenya
}

\author{
Damiano Kulundu Manda, PhD \\ Mercy G. Mugo, PhD \\ James Murunga, MA
}

School of Economics, University of Nairobi, Kenya

Doi:10.19044/esj.2020.v16n22p95 ～URL:http://dx.doi.org/10.19044/esj.2020.v16n22p95

\begin{abstract}
Health inputs are critical in attaining a healthy nation and improving health outcomes. Kenya, like other developing countries, grapples with limited health expenditures and poor population health indicators. Specifically, Kenya is yet to achieve the allocation of least $15 \%$ of the government's annual budget to improve the health sector as enshrined in the Abuja Declaration. Though there is an improvement with regards to infant mortality rate decreasing from 96.6 per 1, 000 live birth in 1970 to 30.6 per 1 , 000 live birth in 2018. This indicator of population health outcome is currently far below the Sustainable Development Goals (SDGs) target of reducing the under five mortality rate to as low as 12 deaths per 1,000 live births by 2030. The literature suggests that increase in government's budgetary allocation to the health sector can improve country's health outcomes. Evidence on the impact of health expenditures on health outcomes is mixed and limited in developing countries. This study aims to analyze the impact of public health expenditures on health outcomes, among other control variables in Kenya. The study uses time series data from 1970 to 2018. The variables are found to be integrated of different orders suggesting the choice of Autoregressive Distributed Lag (ARDL) model. ARDL provides a useful link between long run equilibrium relationships and short run disequilibrium dynamics is estimated. The ARDL bounds test suggests presence of cointegration thus leading to the estimation of Error Correction Model (ECM). The findings suggest that improvements in public health expenditures enhance health outcomes in Kenya. The control variables that are found to be important determinants of infant mortality rate in Kenya include the national income and number of hospital beds per 100, 000. The study recommends that Kenyan government should increase annual budgetary allocation to health sector. Such increase is likely to lead to investments in physical and human capital in the health sector thus translating to improved health outcomes in Kenya.
\end{abstract}


Keywords: Health Expenditures; Health Outcomes; Kenya

\section{Introduction}

A healthy nation is a wealthy nation. Health inputs and outputs are important in attaining a healthy nation. The global health agenda recognizes the role health plays in realizing economic development of especially low- and middle-income countries. This concern is shown by the fact that two (2) out of the seventeen (17) Sustainable Development Goals (SDGs) focus on improvement in health (United Nations, 2015). SDG 3 specifically addresses good health and well-being with the aim to improve life expectancy and reduce some of the common diseases associated with child mortality. The goal also aims at achieving universal health coverage and access to essential drugs and vaccines. Further, the third goal aims to end preventable death of infants and children under five years. The sixth goal is about clean water and sanitation and aims to ensure that countries reduce water-borne diseases and prevent death caused by hazardous chemicals, and air pollution and contamination (United Nations, 2015).

Contrary to the traditionally held view that higher incomes stimulate consumption that promotes health, Bloom \& Canning (2000) posit that there are good reasons and strong evidence showing that improvements in health stimulate economic development. There are several mechanisms through which health improvements can lead to income growth (Deaton, 2003). One such mechanism is that a healthier population tends to have higher labour productivity, live longer and therefore have incentives to save and invest in skills, education and physical capital and eventually benefit from the "demographic dividend". Better health contributes to economic growth and makes investment in health a tool for macroeconomic policy (Aluko \& Adeniji, 2015). Furthermore, investment in health increases human capital that is vital in fostering economic development (Schultz \& Tansel, 1993). Health is also now widely recognized as a basic human right (Gottret \& Schieber, 2006; Republic of Kenya, 2010). Increasing consumption of health services in the population is therefore an important policy issue in many countries.

Most developing countries, Kenya included, strive to achieve favourable health indicators of their populations. Kenya's population health indicators are not favourable (Kimalu et al., 2004). Over the years, infant mortality rate (IMR), under-five mortality rate (U5MR), and maternal mortality rates (MMR) have fluctuated, and remained high. As of 2017, IMR and U5MR stood at 30.6 and 46.4 per 1,000 live births, respectively, while MMR was 342 per 100,000 live births (Kenya National Bureau of Statistics KNBS 2018; WHO, 2019). These indicators of population health status are currently far below the SDGs' target of reducing U5MR to as low as 25 deaths 
per 1,000 live births and to reduce the global MMR to less than 70 per 100,000 live births. Life expectancy at birth increased in the first three decades of Kenya's independence, rising from 44 years in 1963 to 60 years in 1989, but thereafter declined to 53 in 2003, then rising to 66.18 in 2018. Maternal mortality rate, an important indicator of population health, rose from 365 per 100,000 live births during 1988-1994 to 590 during 1988-1998. Although it declined to 414 between 1993 and 2003, it rose again to 560 by 2005 and declined to 342 per 100,000 live births in 2017 (Republic of Kenya, 2008; WHO, 2019). HIV/AIDS, Non-Communicable Diseases (NCDs) and Malaria continue to impose a heavy burden on the health system and the economy in general. While some of the indicators have shown marginal improvements, their levels are still high, fluctuating below global development targets and unfavourable for Kenya's economic growth and development. This calls for sustained investments in healthcare financing.

Despite their efforts to attain better health indicators, developing countries are still a long way in achieving better results. Gottret \& Schieber (2006) point out that most of these countries may not achieve the set targets without substantial increases in health financing. For instance, developing countries account for 84 per cent of the global population and 90 per cent of global burden of disease, but only a small per cent of global GDP and 12 per cent of all health spending. Globally, there is an enormous mismatch between countries' health financing needs and their current health spending, and Kenya is not an exception. Innovations and improvements in the existing financing methods are required if the SDGs and the Kenya Vision 2030 goals are to be achieved.

The importance of health care financing in improving the health of the population cannot be over-emphasized ${ }^{11}$. Health care financing is a key input in the provision of quality health care. Financial resources are required for the provision of health facilities, purchase of drugs and health equipment, personnel remuneration and operations and maintenance (Kimalu et al., 2004). To underscore the importance of health financing, health policy in Kenya revolves around two critical issues: (i) How to deliver a basic package of quality health services to a growing workforce and their dependents; and (ii) how to finance and manage those services in a way that guarantees their availability, accessibility and affordability to those in most need (Kimalu et al., 2004). While the prime concerns of health financing may be how much money is used, how it is raised, how it is spent, who controls it, the impact of these questions goes beyond mere matters of money. The means by which a health service is financed will have significant implications on the way it is

\footnotetext{
${ }^{11}$ Health care financing is a general term, which refers to the resources used to provide health care. While often referring to money, it also includes other resources that are used such as voluntary labour, equipment, supplies or gifts in kind.
} 
run, the care it provides, and on the nature and quality of care provided. Therefore, the way money is raised and spent in Kenya is likely to directly affect service delivery and consequently health outcomes.

Adequate financing of health care services is likely to translate into quality services being delivered and consumed, which subsequently leads to improvements in indicators of population health status. This in turn contributes positively to economic growth through increased health capital stock from investments in health. Most developing countries rely largely on government budget to finance health care services, but these are limited by narrow tax base and inefficient collection capacity of most governments. Even in cases where governments can collect more revenue, the health sector is likely to receive less priority due to competition for funds from other sectors. Although supplemented by user fees, these constitute a very small percentage of public revenue. Options for formal insurance schemes (public or private) are extremely limited due to the small size of the formal employment sector, limited savings, underdeveloped financial sector, and weak institutional environment to support such schemes. As such, households rely on informal arrangements such as extended families, traditional community support systems, Non-Governmental Organizations (NGOs) and charitable organizations to provide protection in the event of catastrophic illnesses (Schieber \& Maeda, 1999).

Kenya, like other developing countries, relies on Government financing through the exchequer (directly to the Ministry of Health and indirectly to other sectors with health-related functions), donors, private sector and NGOs. Most Kenyans have no social health insurance (i.e. National Hospital Insurance Fund - NHIF) ${ }^{12}$ and private health insurance is only accessible to the higher income segment of the population (Mathaeur et al., 2008; KNBS and ICF International, 2015). This situation underscores the fact that Government funds form a vital component of overall health finance. Given that health is often low on the priority list of Government spending, the Ministry of Health budget tends to fall in real terms (Goodman and Waddington, 1993). A general believe is that the achievement of Kenya's health sector policy objectives rests on the Government increasing its budget to the health sector and creating an enabling environment for increased involvement of the private sector, NGOs and communities in the provision of health services. More emphasis needs to be put on preventive rather than the curative services (Kimalu et al., 2004). Although Kenya has endorsed the principles of primary health care laid out in the Alma Ata Declaration of 1978, recurrent expenditure allocations of the Ministry of Health remain skewed in

\footnotetext{
${ }^{12}$ Although NHIF coverage has grown to over 7 million enrolled principal members, translating into over 25 million Kenyans covered considering the dependents, it remains low at about $15 \%$ of population coverage (NHIF, 2018).
} 
favour of curative care, which accounts for about 70 per cent of the total, while preventive and promotive health care including rural health centers account for 19 per cent. Thus, despite policy intentions to reverse the skew, the situation has remained largely the same over the years, partly due to low Government funding to the health sector. Neglect of primary, preventive and promotive health care, despite demonstrated effectiveness in combating most childhood illnesses, has implications on indicators of population health given that a high proportion of morbidity and mortality is from preventable causes. Several studies have been done on the relationship between health outcomes and health expenditures. Most of these studies are in developed countries while those done in developing countries are largely in Latin America, with very few in Sub-Saharan Africa. Studies in Sub-Saharan Africa use panel data on several African countries (Anyanwu \& Erhijakpor, 2009). The studies provide mixed results concerning the relationship, with some showing a strong relationship and others showing no relationship. Indeed, it is important to note that the impact of government expenditure on health may vary from one country to another (Bokhari et al., 2007) and therefore there is need to carry out country-specific studies to inform policy makers in each developing country. Although greater expenditure on health care is advocated for by many in developing countries, Kenya included, little empirical evidence exists on the impact of such expenditure on health outcomes. In Kenya, the only study relating health outcomes to inputs was done by Gakunju (2003). Paucity of evidence in Kenya and mixed results from previous studies necessitates a Kenya-specific study to establish the relationship between public health expenditure and health outcomes.

This study examines the impact of public health expenditure, among other control variables, on one health outcome, namely infant mortality rate (IMR) for Kenya. Lack of reliable time series data limited our analysis on health outcomes such as under-five and maternal mortality rates and life expectancy.

This paper attempts to analyze the impact of Government expenditure on health outcomes in Kenya. A study of the relationship between Government expenditure and health outcomes in Kenya deserves a comprehensive analysis in light of high prevalence of preventable diseases and poor population health indicators, absence of a universal insurance financing system, and low budgetary allocations to the health sector. Analysis of this relationship is important especially for the poor in developing countries due to the fact that they largely obtain health care services from public facilities (Gwatkin, 2000). The findings informs and influence policy on health expenditures and health outcomes in Kenya. 


\subsection{Health Care Expenditure in Kenya: Patterns and Trends}

In Kenya, primarily four agents provide health services, namely: the Ministry of Health (MOH), Non-Governmental Organizations (NGOs), FaithBased Organizations (FBOs), and the private for-profit sector. The $\mathrm{MOH}$ controls 52 per cent of all health facilities while private for-profit sector and FBOs control 36 per cent and 10 per cent, respectively. The NGOs control the remaining 2 per cent of health infrastructure in Kenya (Republic of Kenya, 2018). The public sector is predominantly a tax revenue-funded health system, supplemented by user charges and National Hospital Insurance Fund (NHIF) - formerly catering for formal sector employees but now open to the informal sector. NGOs and private for-profit providers are financed through user charges on their clients' out-of-pocket (OOP) expenditures (Kimani et al., 2016).

Health care financing can be examined in terms of total health expenditures by sources of financing. Figure 1 shows that public expenditure on health increased from over Ksh 49.78 billion to Ksh 97.53 billion between $2014 / 15$ and 2018/19. In terms of expenditure on health relative to total government expenditure, this translated to 5.3 percent of the total government expenditure in 2014/15 and 6.8 percent of the total government expenditure in $2018 / 19$. This increase in budgetary allocations can be attributed to Government's initiation and implementation of Universal Health Coverage (UHC), a programme that aims to transform the country's health sector. The initiative seeks to improve the quality of healthcare services in all public and private healthcare facilities while ensuring that quality services are available, affordable and efficient to all Kenyans. To ensure UHC is achieved, various reforms were implemented in the primary health care to advance publicprivate partnerships in health provision. Per capita expenditure on health increased from Ksh 1,082 to Ksh 1,962 between 2014/15 and 2018/19 (Republic of Kenya, 2019). However, Kenya's per capita health expenditure is still below the World Health Organization (WHO) recommendation of US\$ 34 (Ksh 3,400) to provide an essential package of health service. Thus, the resources for health care finance are scarce in Kenya. 
Figure 1: Kenya government expenditure on health, 2014/15-2018/19

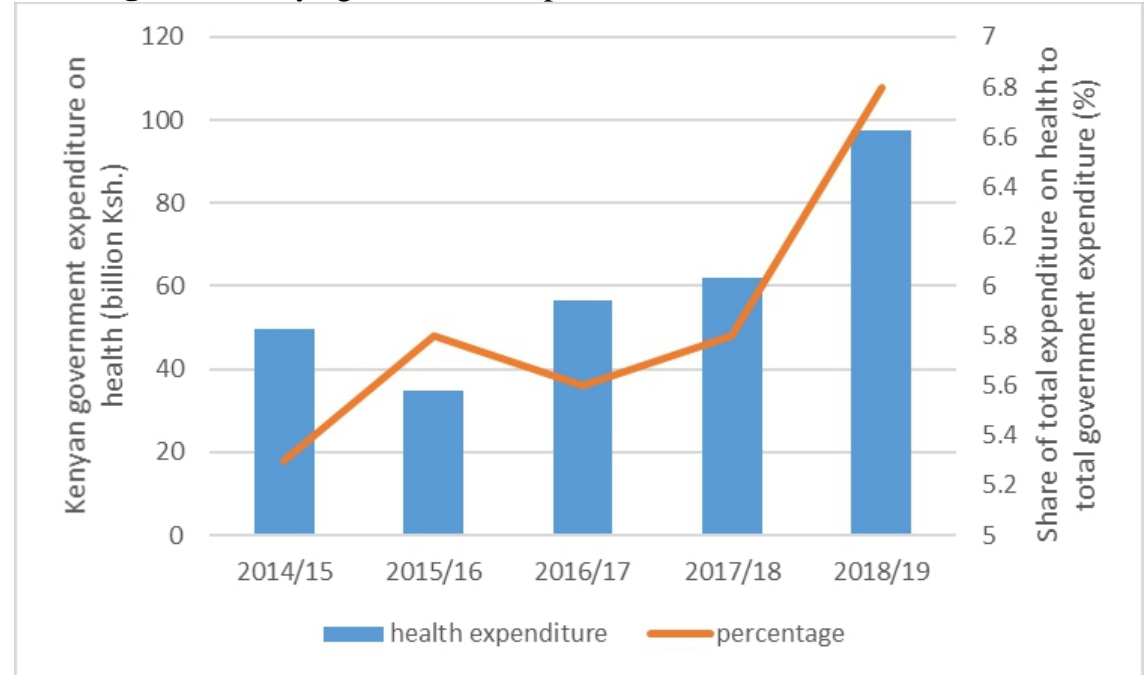

Source: KNBS (2019)

The development budget for the health sector in Kenya includes funds provided by the National Government and donors in form of loans and grants. The information on amount and share contributed from each of the sources between 2016/17 and 2018/19 are presented in Figure 2.

Figure 2: Composition of development budget, 2016/17-2018/19 (\%)

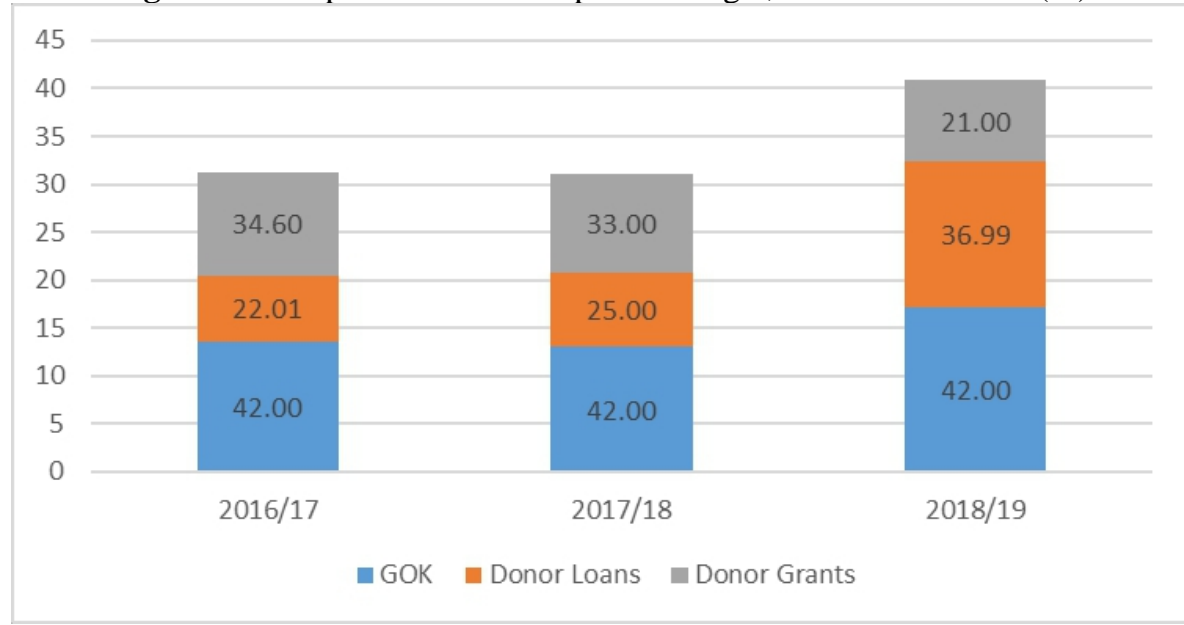

Source: KNBS (2018)

Figure 2 shows that while Government of Kenya (GOK) contribution to development budget remained at 42 per cent, donor loans rose by nearly the same percentage as the decline in grants. Donor loans and grants contributed nearly 58 per cent over the period. The Ministry of Health (MOH) development budget rose significantly from Ksh 31.3 billion and Ksh 31.0 billion during 2016/17 and 2017/18, respectively, to Ksh 40.9 billion in 
2018/19 (Republic of Kenya, 2018). The increase during 2018/19 can be linked to the Government contribution, which rose from Ksh 11.6 billion during 2016/17 to Ksh 17.2 billion in 2018/19, and donor loans increasing from Ksh 6.9 billion during 2016/17 to Ksh 15 billion during 2018/19. Over this period, donor grant declined from Ksh 13.1 billion to Ksh 8.7 billion in $2018 / 19$. This shows that donors are reducing their contributions to the Ministry budget through grants. The trend also shows that there is need for the Government to increase budgetary allocation to the Ministry of Health to replace the dwindling donor funding, thereby reducing donor dependency.

The Kenya's Ministry of Health development resources during 2018/19 targeted areas that are critical in achieving Universal Health Coverage (UHC). Hiring of medical equipment and free maternity health programme accounted for 54 per cent and 25 per cent, respectively, of the Ministry development budget (Republic of Kenya, 2018). The Ministry of Health raised the share of recurrent expenditure to 55 per cent during 2018/19 from 49 per cent and 48 per cent during 2017/18 and 2016/17, respectively. In absolute terms, Ksh 49.1 billion was allocated to recurrent budget by the Ministry during 2018/19. The allocation to personnel emoluments increased from 5.7 per cent in 2016/17 and 2017/18 to about 8 per cent of recurrent budget in 2018/19 (Republic of Kenya, 2019).

The proportion allocated to curative services by the Ministry of Health remained the highest at 45 per cent during 2018/19, an expansion of 71 per cent between 2016/17 and 2018/19. The Ministry allocation for preventive and promotive services remained constant at 11 per cent over the same period (Republic of Kenya, 2018). These statistics suggests that curative health tops the list of public health expenditure in Kenya, while preventive and promotive health dominate on the lower end. Spending on preventive and promotive care is alarmingly low for Kenya whose current Kenya Health Sector Strategic and Investment Plan (KHSSPI 2013-2017) focus is on primary health care through community interventions and preventive care at the rural health facility level (Republic of Kenya, 2013), with similar statements reiterated in the 2012 Health Sector flagship projects in the Kenya Vision 2030. This situation clearly contradicts the stated policy objectives for the health sector. It is now widely acknowledged that the major killer diseases of children are preventable.

\section{Literature Review: Health Expenditure and Outcomes}

Two distinctive approaches have been used to analyze the relationship between Government health expenditures and health outcomes, both rooted in the work of Grossman on human capital theory (Grossman, 1972). First, the theory regards health as both a consumption and investment good. In consuming health, the individual aims at maximizing utility subject to a budget 
constraint, together with characteristics that have an impact on an individual health. Within this model, income and education level play prominent roles as explanatory variables. The model further distinguishes between health and health care, the latter being one of the many inputs into production of commodity health. The investment model of demand deals with a theoretical and empirical investigation of demand for the commodity health. The model regards health as a capital good that is inherited and depreciates over time. According to the theory, investment in health is a process in which medical care is combined with other relevant factors to produce new health, which in part offsets the process of depreciation of the health stock.

The second approach considers health within a production function framework. The basic tenet of this approach is that health is an output of a health care system, which is influenced by the inputs to the system. This approach is useful when investigating the relationship between health care expenditures (as inputs) and health outcomes (as outputs) of the system. Our empirical analysis focuses on the second approach, which is suitable for macro level data analysis. Macro level analysis is more appropriate considering that, analytically and empirically, micro-level results for health policy decision making at the macro level can be misleading (Nixon \& Ulmann, 2006).

Several studies have been carried out on the relationship between health outcomes and inputs, with most of the studies (Anyanwu \& Erhijakpor, 2009) utilizing cross-country panel data. Measures and processes of measurement of population health are varied and imperfect, resulting in many indicators of population health ranging from crude indicators such as birth and death rates, mortality and morbidity indicators to quality adjusted measures such as Quality Adjusted Life Years (QALYs) and Disability Adjusted Life Years (DALYs) (Mugo, 2004). However, Nixon and Ulmann (2006) in a review of several studies demonstrate that majority of studies use mortality rates (age-specific or infant mortality) and life expectancy (Barlow \& Vissandjee, 1999) as measures of population health outcomes. This is consistent with the Millennium Development Goals (MDGs) and the Sustainable Development Goals (SDGs) indicators (United Nations, 2015).

Studies analyzing the impact of public spending on health outcomes include some measure of health expenditure as one of the independent variables. Health expenditure as a share of GDP and per capita health expenditure are commonly used as independent variables. The range of socioeconomic variables varies across studies based on data availability, setting and relevance. However, most studies include health system variables such as medical personnel density (physicians and nurses per 100,000 population), hospital beds and cots, demographic and economic variables (Cremiux et al., 2005; Cremiux et al., 1999), education index, proportion of health expenditure covered by government (Hitiris \& Possnett, 1992), and dietary consumption 
such as alcohol consumption and calorie intake. Other specific variables include decentralization coefficient (Robalino et al., 2001), political rights and proportion of white-collar workers (Or, 2000).

Studies on health expenditures and health outcomes show mixed findings, with some studies (Gupta et al., 2001; Gupta et al., 1999; Hojman, 1996; Bokhari et al., 2007; Gani, 2009; Aisa et al., 2014; Bein et al., 2017; Jaba et al., 2014; Akinci, et al., 2014) finding support for health expenditures reducing the mortality rates while others find no effect (Deolalikar, 2005). Most of these studies are cross-country studies with very few country-specific studies. The impact of government expenditure on health may vary from one country to another largely because countries have different levels of income, education, infrastructure (network of road, access to improved water sources and sanitation), among others (Bokhari et al., 2007).

Literature suggests that in modeling the relationship between health expenditures and health outcomes, issues of reverse causality and heterogeneity should be accounted for. There may be reverse causality between the explanatory variables and the health outcomes. For instance, not only is the income of individuals likely to affect health status, but their health status may also affect their income (Wagstaff, 2002). Similarly, government expenditures on health and other sectors may also be endogenous to health outcomes because governments may respond by changing expenditures on health and education to changes in health outcomes. Since income and government expenditures are potentially endogenous, literature suggests use of relevant and valid instruments to minimize bias and misinterpretation of coefficients (Stock et al., 2002; Murray, 2006a; Murray, 2006b). While acknowledging the need for controlling for endogeneity and heterogeneity, this study did not incorporate these new methodologies at initiation. Also, in view of the time series nature of the data and the need to analyze short and long-run relationships, we utilize an Autoregressive Distributed Lag Model (ARDL). Nevertheless, a follow-up study to cater for these econometric challenges using cross-section data is necessary, and the authors call for exercise of caution in interpretation of findings.

\section{Methodology}

\subsection{Model Specification}

We examine the impact of public health expenditures on health outcomes through an empirical framework relating the key health outcomes to government health expenditures, controlling for other influencing variables. The inputs to the system are determined by, among other things, government health expenditures and how this expenditure is allocated within the sector. The model is estimated using time series data on Kenya. We use infant mortality rate as a proxy for health outcomes. This is consistent with previous 
studies. The basic equations examine the direct impact of Government health spending on health outcomes, proxied by infant mortality rate (IMR). The IMR refers to the number of infants dying before reaching one year of age per 1,000 live births in a given year. The specified model is presented below.

$I M R=\beta_{0}+\beta_{1} P H+\beta_{2} Y+\beta_{3} F L+\beta_{4} N D P+\beta_{5} N H B P+\varepsilon \ldots \ldots \ldots \ldots \ldots \ldots . . .1$

Where:

IMR = Infant mortality rate

$\mathrm{PH}=$ Public expenditure on health

$\mathrm{Y}=$ National income

$\mathrm{FL} \quad=$ Female literacy rate

NDP $=$ Number of doctors per 100,000 population

NHBP $=$ Number of hospital beds per 100,000 population

$\varepsilon \quad=$ Error term

In the literature, infant mortality rate is considered a better indicator of the health status of the population. Long term improvements in the health status of the population are best reflected in infant mortality rate (Gupta \& Mitra. 2004). Infant mortality rate is regarded as a sensitive indicator of the availability, utilization and effectiveness of health care and is commonly used for comparing health care systems, monitoring, and designing population and health programmes. IMR generally reflects the level of mortality and the effectiveness of preventive care, and the attention paid to maternal and child health (Anyanwu \& Erhijakpor, 2009).

The health outcomes are presumed to be primarily a function of public health expenditure, and other socio-economic control factors. The variables controlled for in many of the studies are as follows: national income, doctors per 100,000 population and number of hospital beds and cots per 100,000 population. Table 1 presents variables used in the analysis, and their definitions.

According to the literature, an increase in public health expenditure (an indicator of the volume of resource flowing into the health sector) is expected to have a negative effect on infant mortality rates. An increase in public health expenditure would imply broader access to health care and services, which helps to reduce infant mortality rates. Literacy rate and especially female literacy is an important determinant of health status of infant mortality rates, and the population in general (Baldacci et al., 2004). In developing countries such as Kenya, women play an important role in family health and sanitation. In addition, female education is positively associated with improved infant health. Educated mothers are likely to be aware of nutrition and their children's health (Currie \& Moretti, 2003). Thus, a mother's socio-economic status is believed to affect infant survival chances. In fact, one of the most frequently used explanatory variables in the literature is mother's education, 
also used to proxy other characteristics of the mother, the household and community.

Table 1: The variables and their definitions

\begin{tabular}{|l|l|}
\hline \multicolumn{1}{|c|}{ Variable } & \multicolumn{1}{c|}{ Definition } \\
\hline Infant mortality rate & $\begin{array}{l}\text { The number of infants dying before reaching one } \\
\text { year of age per 1,000 live births in a given year }\end{array}$ \\
\hline Public health expenditure & $\begin{array}{l}\text { Total public expenditure on the health sector in } \\
\text { Kenya shillings }\end{array}$ \\
\hline National income & $\begin{array}{l}\text { Real gross national income in Kenya shillings } \\
\text { divided by the population }\end{array}$ \\
\hline Doctors per 100,000 population & $\begin{array}{l}\text { The total number of doctors per } 100,000 \\
\text { population }\end{array}$ \\
\hline $\begin{array}{l}\text { Number of hospital beds and cots } \\
\text { per } 100,000\end{array}$ & $\begin{array}{l}\text { Number of hospital beds and cots per } 100,000 \\
\text { population }\end{array}$ \\
\hline Female literacy rate & Proportion of women who can read and write \\
\hline
\end{tabular}

Mortality rates are normally higher among rural, low-income households than in urban households. Also, urban households tend to access better health facilities than rural households. National income has been shown to be an important determinant of health outcomes. It is a proxy for socioeconomic status (standard of living) in a given country and an important proxy for human capital income (Roberts, 2003). A population's health status improves as national income improves, suggesting that increasing incomes would be associated with lower infant mortality rates. Higher incomes also lead to improved public health infrastructure such as water and sanitation, better nutrition, better housing and the ability to pay for health care (Cutler et al., 2006). According to basic economic theory, if everything else remains unchanged and if health care is a normal good, an increase in national income will lead to an increase in the demand for health care. Income also increases the capacity of the government and other players to supply more and better quality health care and to improve access to health care through better infrastructure.

The number of physicians per 100,000 population is also important as a direct medical input, and indicates access to medical care. It is a vector of knowledge facilitating medical technology absorption and the adoption of best practices, and is expected to lower the mortality rates (Ricci \& Zachariadis, 2006). The higher the density of doctors, the more likely that infant mortality rates would decline.

\subsection{Data Sources}

Data used in this study was collected from various sources. Data on infant mortality rate was obtained from UNICEF database. Data on the number of doctors per 100,000 population, national income, public health expenditure and number of hospital beds and cots per 100,000 population was obtained 
from various statistical abstracts and economic surveys (Kenya National Bureau of Statistics -KNBS). Time series data covering the period 1970 to 2018 was constructed from the above sources and formed the basis of analysis for this study.

\subsection{Pre-estimation Tests}

To avoid cases of spurious regression, the study performed unit root tests. Appropriate methods for testing the presence of unit roots in the data series is the Augmented Dickey Fuller (ADF) test, the Phillips-Peron (PP)-test and Zivot-Andrews (Z-A) test. PP test is the most used alternative to ADF since it is non-parametric. It does not require model specification and lagged parameter in the test regression. However, PP may not be the best test because it is based on asymptotic theory. In other words, PP test is designed to test the unit root in the long time series, which is not possible in reality. Zivot (1992) and Pesaran (2015) show that both ADF and PP tests are asymptotically equivalent. These authors further asserted that both tests have lower power, and invalid null hypothesis is not rejected in the situation where the coefficient in AR (1) process is close to one. Further, these conventional unit root tests do not account for structural breaks in the data. The unit root that overcomes all these drawbacks is Z-A unit root test. The nature of aggregate time series data requires that unit root tests be conducted before any regression is carried out. If data is non-stationary ${ }^{13}$, this would lead to spurious or inconsistent regression results. The unit roots tests were performed using the ADF test, the PP test and Z-A test, where the null hypothesis is that the series tested contains at least a unit root. Having established the nature of the stationarity of the variables, the study investigated for presence of long run relationship using the ARDL bounds test (Enders, 2015).

\section{Results}

\subsection{The Descriptive Statistics}

Table 2 presents descriptive statistics of the data used. Average infant mortality rate over the period was 66.8 deaths per 1,000 live births and ranged from 30.1 to 96.6 . The average number of doctors per 100,000 population was 15 but the variation in the number of doctors per 100,000 is very small as shown by the standard deviation, probably reflecting the duration and cost of training of qualified doctors. This ratio is far below the European average of

\footnotetext{
${ }^{13}$ Data points are non-stationary if they have means, variances and covariances that change over time. Such data are unpredictable and cannot be modeled or forecasted and are said to have unit roots. Testing for unit roots determines if or not the data series are non-stationary. Through differencing and detrending, the data can be made stationary, or adopt suitable methods that can model non-stationary variables with subsequent meaningful coefficient estimations and forecasting.
} 
350 doctors per 100,000 population. However, it is higher than for other Eastern Africa countries (Uganda 8; Rwanda 5; Burundi 3; Tanzania 2; and Ethiopia 3). On average, the number of hospital beds and cots per 100,000 population is 156 and has ranged from 125 to 192 over the period. The public expenditure on health over the study period averaged Kshs 17,548.6 million but the variation in the expenditure has also been high as shown by the standard deviation. The national income has also changed and has large dispersion as shown by the standard deviation.

Table 2: Descriptive statistics $(n=49)$

\begin{tabular}{|l|r|r|r|r|}
\hline Variable & \multicolumn{1}{|c|}{ Mean } & Std. Dev. & \multicolumn{1}{c|}{ Min } & \multicolumn{1}{c|}{ Max } \\
\hline Infant mortality rate & 66.8 & 15.3 & 30.1 & 96.6 \\
\hline Public health expenditure (Ksh millions) & $17,548.6$ & $23,988.4$ & 300.9 & 108,100 \\
\hline Doctors per 100,000 population & 15 & 4 & 8 & 24 \\
\hline $\begin{array}{l}\text { Number of hospital beds and cots per } \\
100,000 \text { population }\end{array}$ & 156 & 18 & 125 & 192 \\
\hline Female literacy rate (\%) & 71.3 & 8.4 & 53.2 & 85 \\
\hline National income (Ksh millions ) & $1,430,192$ & $2,238,242$ & 10,332 & $8,904,984$ \\
\hline
\end{tabular}

Source: Author's computations

\subsection{The Unit Root Results}

Table 3 presents ADF and PP unit root test results for determining whether a variable has at least a unit root or is stationary.

The test results show that all variables are non-stationary at level while using both ADF and PP tests. The infant mortality rate and national income were revealed to be integrated of order two while the other variables were revealed to be integrated of order one.

Table 3: ADF unit roots tests

\begin{tabular}{|c|c|c|c|c|c|c|c|}
\hline \multicolumn{5}{|c|}{ Augmented Dickey Fuller } & \multicolumn{3}{|c|}{ Phillips-Perron } \\
\hline Variable & $\begin{array}{l}\text { Level of } \\
\text { Testing }\end{array}$ & Statistic & $\begin{array}{l}\text { Critical } \\
\text { Value (5\%) } \\
\end{array}$ & $\begin{array}{l}\text { Order of } \\
\text { Integration }\end{array}$ & Statistic & $\begin{array}{l}\text { Critical } \\
\text { Value (5\%) }\end{array}$ & $\begin{array}{l}\text { Order of } \\
\text { Integration }\end{array}$ \\
\hline $\begin{array}{l}\text { Infant } \\
\text { mortality rate } \\
\text { per 1,000 live } \\
\text { births }\end{array}$ & $\begin{array}{l}\text { Level } \\
1^{\text {st }} \mathrm{D} \\
2^{\text {nd }} \mathrm{D}\end{array}$ & $\begin{array}{l}0.738 \\
-1.651 \\
-10.156\end{array}$ & $\begin{array}{l}-2.936 \\
-2.938 \\
-2.941\end{array}$ & $\mathrm{I}(2)$ & $\begin{array}{l}0.121 \\
-1.558 \\
-11.558\end{array}$ & $\begin{array}{l}-2.936 \\
-2.938 \\
-2.941\end{array}$ & $\mathrm{I}(2)$ \\
\hline $\begin{array}{l}\text { Public health } \\
\text { expenditure }\end{array}$ & $\begin{array}{l}\text { Level } \\
1^{\text {st }} \mathrm{D}\end{array}$ & $\begin{array}{r}0.570 \\
-6.303\end{array}$ & $\begin{array}{l}-2.936 \\
-2.938\end{array}$ & $\mathrm{I}(1)$ & $\begin{array}{l}2.100 \\
-6.087\end{array}$ & $\begin{array}{l}-2.936 \\
-2.938\end{array}$ & $\mathrm{I}(1)$ \\
\hline $\begin{array}{l}\text { Doctors per } \\
100,000 \\
\text { population }\end{array}$ & $\begin{array}{l}\text { Level } \\
1^{\text {st }} \mathrm{D}\end{array}$ & $\begin{array}{l}-0.475 \\
-8.946\end{array}$ & $\begin{array}{l}-2.936 \\
-2.938\end{array}$ & $\mathrm{I}(1)$ & $\begin{array}{l}0.144 \\
-9.581\end{array}$ & $\begin{array}{l}-2.936 \\
-2.938\end{array}$ & $\mathrm{I}(1)$ \\
\hline $\begin{array}{l}\text { Hospital beds } \\
\text { and cots per } \\
100,000 \\
\text { population }\end{array}$ & $\begin{array}{l}\text { Level } \\
1^{\text {st }} \mathrm{D}\end{array}$ & $\begin{array}{l}-2.424 \\
-6.482\end{array}$ & $\begin{array}{l}-2.936 \\
-2.938\end{array}$ & $\mathrm{I}(1)$ & $\begin{array}{l}-2.579 \\
-6.482\end{array}$ & $\begin{array}{l}-2.936 \\
-2.938\end{array}$ & $\mathrm{I}(1)$ \\
\hline $\begin{array}{l}\text { Female } \\
\text { literacy rate }\end{array}$ & $\begin{array}{l}\text { Level } \\
1^{\text {st }} \mathrm{D}\end{array}$ & $\begin{array}{l}-1.744 \\
-4.809\end{array}$ & $\begin{array}{l}-2.936 \\
-2.938\end{array}$ & $\mathrm{I}(1)$ & $\begin{array}{l}-1.625 \\
-4.595\end{array}$ & $\begin{array}{l}-2.936 \\
-2.938\end{array}$ & $\mathrm{I}(1)$ \\
\hline $\begin{array}{l}\text { National } \\
\text { income }\end{array}$ & $\begin{array}{l}\text { Level } \\
1^{\text {st }} D \\
2^{\text {nd }} D\end{array}$ & $\begin{array}{l}11.609 \\
-1.754 \\
-11.142\end{array}$ & $\begin{array}{l}-2.936 \\
-2.938 \\
-2.941\end{array}$ & $\mathrm{I}(2)$ & $\begin{array}{l}14.353 \\
-1.029 \\
-14.238\end{array}$ & $\begin{array}{l}-2.936 \\
-2.938 \\
-2.941\end{array}$ & $\mathrm{I}(2)$ \\
\hline
\end{tabular}

Source: Author's computation 
Table 4 presents Z-A unit root test results. The test results revealed that some variables were stationary while others were non-stationary. For instance, in contrast to $\mathrm{ADF}$ and $\mathrm{PP}$ test results, infant mortality rate, doctors per 100,000 population and female literacy rate were found to be stationary at levels. The remaining variables were found to be integrated of order one.

Table 4: Zivot-Andrews unit root test

\begin{tabular}{|c|c|c|c|c|}
\hline \multicolumn{5}{|l|}{ Trend and Intercept } \\
\hline \multirow{2}{*}{ Variables } & \multirow{2}{*}{$\begin{array}{l}\text { Year of } \\
\text { structural } \\
\text { break }\end{array}$} & & \multirow[b]{2}{*}{$\begin{array}{l}\text { t- } \\
\text { statistics }\end{array}$} & \multirow[b]{2}{*}{$\begin{array}{l}5 \% \text { critical } \\
\text { value }\end{array}$} \\
\hline & & & & \\
\hline \multirow{2}{*}{$\begin{array}{l}\text { Infant mortality rate } \\
\text { per } 1,000 \text { live births }\end{array}$} & \multirow[t]{2}{*}{2011} & Level & -6.913 & -4.42 \\
\hline & & Conclusion & \multicolumn{2}{|l|}{$I(0)$} \\
\hline \multirow[t]{2}{*}{$\begin{array}{l}\text { Public health } \\
\text { expenditure }\end{array}$} & \multirow[t]{2}{*}{$\begin{array}{l}2005 \\
2010\end{array}$} & $\begin{array}{l}\text { Level } \\
1^{\text {st }} \mathrm{D}\end{array}$ & $\begin{array}{l}-3.516 \\
-8.354\end{array}$ & $\begin{array}{l}-4.42 \\
-4.42\end{array}$ \\
\hline & & Conclusion & \multicolumn{2}{|l|}{$I(1)$} \\
\hline \multirow{2}{*}{$\begin{array}{l}\text { Doctors per } 100,000 \\
\text { population }\end{array}$} & \multirow[t]{2}{*}{2009} & Level & -4.746 & -4.42 \\
\hline & & Conclusion & \multicolumn{2}{|l|}{$I(0)$} \\
\hline
\end{tabular}

Source: Author's Computation

Table 4: Zivot-Andrews unit root test Continued

\begin{tabular}{|c|c|c|c|c|}
\hline \multirow{2}{*}{$\begin{array}{c}\text { Hospital beds and } \begin{array}{c}\text { cots per 100,000 } \\
\text { population }\end{array} \\
\text { Female literacy rate }\end{array}$} & 2001 & $\begin{array}{c}\text { Level } \\
1^{\text {st }} \mathrm{D}\end{array}$ & $\begin{array}{c}-2.752 \\
-4.633\end{array}$ & -4.42 \\
\cline { 3 - 5 } & \multirow{2}{*}{1980} & Conclusion & \multicolumn{3}{|c|}{$\mathrm{I}(1)$} \\
\hline \multirow{2}{*}{ National income } & 2009 & Level & -5.356 & -4.42 \\
\cline { 3 - 5 } & 2006 & Conclusion & \multicolumn{2}{|c|}{$\mathrm{I}(0)$} \\
\cline { 3 - 5 } & & Level & -1.873 & -4.42 \\
\cline { 3 - 5 } & & $1^{\text {st }} \mathrm{D}$ & -5.819 & -4.42 \\
\hline
\end{tabular}

Source: Author's Computation

Since the Z-A results showed that the variables were integrated of different orders, Autoregressive Distributed Lag Model (ARDL) was adopted. This model was developed by Pesaran et al. (2001). The model has three advantages compared to other models. The first advantage is that ARDL does not require that all variables used in the study be integrated of the same order. This means the model is suitable if variables are integrated of order zero, one or fractionally integrated. Secondly, ARDL model is relatively efficient in the situation of small and finite sample data sizes. Lastly, use of ARDL model results to unbiased long run estimates (Harris and Sollis, 2003).

\subsection{The ARDL Bounds Test Results}

Since the nature of the unit root suggested the choice of ARDL model, there was need to investigate presence of long run relationship among the variables. The ARDL bounds test results shown in Table 5 revealed the presence of cointegration between the dependent variables and the explanatory 
variables considered in the model. This was evidenced by an F-test that was greater than Pesaran \& Shin (1998) critical values of 1(1) bound, thus rejecting the null hypothesis of no cointegration.

Table 5: ARDL bounds test Results

\begin{tabular}{|l|r|}
\hline F-statistic & 19.423 \\
\hline $\mathrm{I}(0)$ at 5\% significance level & 2.62 \\
\hline $\mathrm{I}(1)$ at 5\% significance level & 3.79 \\
\hline
\end{tabular}

\subsection{Regression Results}

Having established presence of cointegration, the study estimated the Error Correction Model (ECM). The results are shown in Table 6. The diagnostic tests revealed that the study's results are valid. The study obtained Breusch-Godfrey statistic of 0.000 , which led to failure to reject the null hypothesis of no autocorrelation. The study also ruled out presence of endogeneity, since the Durbin-Wu-Hausman test for endogeneity was not statistically significant at the $5 \%$ level of significance. A requirement for existence of a long run relationship is negative and significant Error Correction Term (ECT). Our findings showed that the coefficient of ECT is negative and significant, an ideal condition that ensures convergence in the model. This indirectly implies that there is a significant long run relationship among the variables. The coefficient of error term reveals that if there was deviation from the equilibrium, it woud take 0.1283 years for it to be restored.

Table 6: ARDL regression results

\begin{tabular}{|c|c|}
\hline Dependent Variable: Infant Mortality Rate & Coefficients \\
\hline Error Correction Term (ECT) & $\begin{array}{c}-0.1283 * * * \\
(0.0245)\end{array}$ \\
\hline \multicolumn{2}{|c|}{ Long Run Relationship } \\
\hline Public expenditure on health & $\begin{array}{c}-0.0003 * * * \\
(0.0001)\end{array}$ \\
\hline Number of doctors per 100,000 population & $\begin{array}{l}-0.548 \\
(0.984) \\
\end{array}$ \\
\hline Number of hospital beds per 100,000 population & $\begin{array}{c}-0.132^{*} \\
(0.066)\end{array}$ \\
\hline National income & $\begin{array}{c}-7.01 * * * \\
(2.23)\end{array}$ \\
\hline Female literacy rate & $\begin{array}{l}-0.243 \\
(0.287)\end{array}$ \\
\hline \multicolumn{2}{|c|}{ Short Run Relationship } \\
\hline Lag one of the difference of infant mortality & $\begin{array}{c}-0.8445 \\
(0.145)\end{array}$ \\
\hline Lag two of the difference of infant mortality & $\begin{array}{c}1.748^{* * *} \\
(0.162)\end{array}$ \\
\hline Difference of national income & $\begin{array}{c}2.01 * * * \\
(8.29)\end{array}$ \\
\hline Lag one of the difference of national income & $\begin{array}{c}2.81 * * * \\
(7.62)\end{array}$ \\
\hline
\end{tabular}




\begin{tabular}{|l|c|}
\hline Adj R-squared & 0.8937 \\
\hline Breusch-Godfrey LM test for autocorrelation & 0.000 \\
\hline Durbin-Wu-Hausman test for endogeneity & 0.0882 \\
\hline
\end{tabular}

Standard errors in parentheses. $* * * \mathrm{p}<0.01, * * \mathrm{p}<0.05, * \mathrm{p}<0.1$

The coefficients of the long run relations were the ones that were important for this study because the effect of the chosen regressors on infant mortality would not be noticeable within the same year. The study results revealed that public expenditure on health is important for health outcomes in the country. This was evidenced by a negative and significant coefficient of the public expenditure on health in the long run. The signs of the other regressors agreed with economic theory. For instance, the study revealed that the number of hospital beds per 100,000 population, national income and female literacy rate were important determinants of health outcomes in Kenya. The coefficient of number of doctors per 100,000 population was positive as expected but insignificant. This may imply that doctors may not individually lead to decrease in infant mortality rate; instead, they need to work in collaboration with other medical and non-medical personnel.

Specifically, the results revealed that an increase in public health expenditure by one unit leads to a reduction in infant mortality rate by 0.0003 units in the long run, holding other factors constant. In addition, holding other factors constant, an increase in number of hospital beds per 100,000 population and national income individually leads to reduction in infant mortality rate by 0.132 and 7.01 units in the long run, respectively. Further, infant mortality rate declines by 0.243 units if female literacy rate is increased individually by one unit, holding other factors constant.

\section{Conclusion and Policy Recommendations}

This paper examined the impact of public health expenditures among other variables on infant mortality rate. The study is based on time series data covering the period 1970 to 2018. Appropriate econometric tests to detect for presence of autocorrelation, endogeneity, non-stationarity and cointegration were conducted. The study found absence of autocorrelation and endogeneity. Unit root tests revealed a mixture of stationary and non-stationary variables, thus leading to adoption of ARDL model. The ARDL bounds test revealed presence of cointegration leading to estimation of error correction model. Results based on the long-run regression show that public health expenditures reduce the infant mortality rate in Kenya. The control variables that were found to influence health outcomes in Kenya include the number of hospital beds per 100,000 population, national income, and female literacy rate.

This study substantially improves understanding of the link between public health expenditure and health outcomes. The study findings showed that increasing public health expenditure improves health outcomes in Kenya. 
These findings have significant implications for enhancing public health expenditure in Kenya. According to World Bank (2013) and NHIF (2018), only 20 per cent of people in Kenya have access to medical insurance. This means that Kenya's health sector is marred by inequalities as a result of poverty. Thus, increase in public health is key in ensuring universal coverage in Kenya, thus translating into improved health outcomes. In addition, attainment of the SDG of better health relies heavily on public health expenditure.

Our findings draw the following policy recommendations. First, literature has established that public health expenditure improves health outcomes. Empirically, it has been established that increase in public expenditure improves health outcomes in Kenya. Thus, the Kenyan Government needs to increase budgetary allocation to the Ministry of Health, which will translate into increased health investments in terms of both physical and human capital, for instance bed cots that are critical in improving health outcomes, and the much needed human resources for health. In addition, the Government should put in place measures that will lead to advancement of female literacy levels. We recommend a policy that supports increased participation of females in enrolment, completion, and attainment of at least secondary level of education to achieve better health outcomes for all.

\section{References:}

1. Aisa, R., Clemente, J. \& Pueyo, F. (2014). The influence of health expenditure on longevity: A reconsideration. International Journal of Public Health, 59 (5), 867-875.

2. Akinci, F., Hamidi, S., Suvankulov, F. \& Akhmedjonov, A. (2014). Examining the impact of health care expenditures on health outcomes in the Middle East and N. Africa. Journal of Healthcare Finance, 41 (1), 1-23.

3. Aluko, O. O. \& Adeniji, O. O. (2015). Exploring the effect of health on economic growth in Nigeria: A vector error correction model approach. International Journal of Economics, Commerce and Management, 3(9), 659-678.

4. Anyanwu, J.C. \& Erhijakpor A.E.O. (2009). Health expenditures and health outcomes in Africa. African Development Review, 21(2), 40033.

5. Baldacci, E., Clements, B., Gupta, S. \& Cui, Q. (2004). Social spending, human capital and growth in developing countries: Implication for achieving MDGs. IMF Working Paper No. WP/04/217. Washington DC: International Monetary Fund.

6. Barlow, R. \& Vissandjee, B. (1999). Determinants of national life expectancy. Canadian Journal of Development Studies, 20, 9-28. 
7. Bein, M.A., Unlucan. D., Olowu, G. \& Kalifa, W. (2017). Healthcare spending and health outcomes: Evidence from selected East African countries. African Health Sciences, 17(1), 247-254.

8. Bloom, D.E. \& Canning, D. (2000). The health and wealth of nations. Science, 287(5456), 1207-1209.

9. Bokhari A. S. F., Gai, Y. \& Gottret, P. (2007). Government health expenditures and health outcomes. Health Economics, 16, 257-273.

10. Cremiux, P.Y., Mielleur, M.C., Quellette. P., Petit, P., Zelder, P. and Potvin, K. (2005). Public private pharmaceutical spending as a determinant of health outcomes in Canada. Health Economics, 14, 107-116.

11. Cremiux, P.Y., Quellette, P. \& Pilon, C. (1999). Health care spending as determinant of health outcomes. Health Economics, 8, 627-639.

12. Currie, J. \& Moretti, E. (2003). Mother's education and the intergenerational transmission of human capital: Evidence from college openings. Quarterly Journal of Economics, 118 (4): 14951532.

13. Cutler, D., Deaton, A. \& Lleras-Muney, A. (2006). The determinants of mortality. Journal of Economic Perspectives, 20(3), 97-120.

14. Deaton, A. (2003). Health, inequality and economic development. Journal of Economic Literature, 41(1), 113-158.

15. Deolalikar, A. (2005). Attaining the Millennium Development Goals in India: How likely and what will it take to reduce infant modality, child malnutrition, gender disparities and hunger-poverty and to increase enrollment and completion. New Delhi: Oxford University Press.

16. Enders, W. (2015). Applied Econometric Time Series. New Jersey: John Wiley \& Sons.

17. Gakunju, E. M. (2003). Determinants of health status in Kenya. Unpublished MA project, Makerere University, Uganda.

18. Gani, A. (2009). Health care financing and health outcomes in Pacific Island countries. Health Policy and Planning, 24, 72-81.

19. Goodman, H. \& Waddington, C. (1993). Financing health care. Oxford: Oxfam Publication Department.

20. Gottret, P. \& Schieber, G. (2006). Health financing revisted: A practioners' guide. Washington DC: World Bank.

21. Grossman, M. (1972). On the concept of health capital and the demand for health. Journal of Political Economy, 80(2), 223-255.

22. Gupta, I. \& Mitra, A. (2004). Economic growth, health and poverty: An exploratory study for India". Development Policy Review, 22, 193206.

23. Gupta, S., Verhoeven, M. \& Tiogson, E. (1999). Does government spending buy better results in education and health care? IMF 
Working Paper No. WP/99/21. Washington DC: International Monetary Fund.

24. Gupta, S., Verhoeven, M. \& Tiogson, E. (2001). Public spending on health care and the poor. IMF Working Paper No. WP/01/127. Washington DC: International Monetary Fund.

25. Gwatkin, D. R. (2000). Health inequalities and the health for the poor: What do we know? What do we do? Bulletin of the World Health Organization, 78, 3-18.

26. Harris, R. \& Sollis, R. (2003). Applied time series modelling and forecasting. West Sussex: Wiley.

27. Hitiris, T. and Possnett, J. (1992). The determinants and effects of health expenditure in developed countries. Journal of Development Economics, 6, 173-181.

28. Hojman, D. E. (1996). Economic and other determinants of infant and child mortality in small developing countries: The case of Central America and Caribbean. Applied Economics, 28, 281-290.

29. Jaba, E., Balan, J.B. \& Robu, I. B. (2014). The relationship between life expectancy at birth and health expenditures estimated by a crosscountry and time-series analysis. Procedia Economics and Finance, $15,108-114$.

30. Kenya National Bureau of Statistics - KNBS and ICF International (2015). Kenya Demographic and Health Survey 2014. Nairobi: Government Printer.

31. Kenya National Bureau of Statistics-KNBS (2018). Economic Survey. Nairobi: Government Printer. Available at https://www.knbs.or.ke.

32. Kenya National Bureau of Statistics-KNBS (2019a). Economic Survey. Nairobi: Government Printer. Available at https://www.knbs.or.ke.

33. Kenya National Bureau of Statistics-KNBS (2019b). Economic Surveys. Nairobi: Government Printer. Available at https://www.knbs.or.ke.

34. Kimalu, P.K., Nafula, N.N., Manda, D.K., Bedi, A., Mwabu, G. \& Kimenyi, M.S. (2004). A review of the health sector in Kenya. KIPPRA Working Paper Series WP/11/2004. Nairobi: Kenya Institute for Public Policy Research and Analysis.

35. Kimani, D. N., Mugo, M. G. and Kioko, U. M. (2016). Catastrophic health expenditures and impoverishment in Kenya. European Scientific Journal, 12(15), 434-452.

36. Mathaeur, I., Schmidt, J.O. \& Wenyaa, M. (2008). Extending social health insurance to the informal sector in Kenya: An assessment of factors affecting demand. International Journal of Health Planning and Management, 23: 51-68. 
37. Mugo, M.G. (2004). Methodological issues in measurement and valuation of disease states: A case study of schistosomiasis mansoni in Kenya. Doctoral Thesis, London School of Hygiene and Tropical Medicine, University of London, UK.

38. Murray, M.P. (1994). A drunk and her dog: An illustration of cointegration and error correction models". The American Statistician, 48 (1), 37-39.

39. Murray, M.P. (2006a). Avoiding invalid instruments and coping with weak instruments. Journal of Economic Perspectives, 20(4), 111-132.

40. Murray, M.P. (2006b). The bad, the weak, and the ugly: Avoiding the pitfalls of instrumental variables estimation. SSRN Working Paper No. 843185, Social Science Research Network, available at WWW.ssrn.com.

41. NHIF (2014). Strategic Plan 2014-2018: Sustainable financing towards Universal Health Coverage in Kenya. http://www.nhif.or.ke/healthinsurance/uploads/strategic_plan/Strategi c_Plan_2014-2018.pdf

42. NHIF (2018). Strides towards Universal Health Coverage for all Kenyans. Nairobi: National Hospital Insurance Fund.

43. Nixon, J. \& Ulmann, P. (2006). The relationship between health and care expenditure and health outcomes. The European Journal of Health Economics, 7: 7-18.

44. Or, Z. (2000). Determinants of health outcomes in industrialized countries: A pooled cross country time series analysis. OECD Economic Studies, 30(1), 53-77.

45. Pesaran, M. H., \& Shin, Y. (1998). An autoregressive distributed-lag modelling approach to cointegration analysis. Econometric Society Monographs, 31, 371-413.

46. Pesaran, M. H., Shin, Y. and Smith, R. J. (2001). Bounds testing approaches to the analysis of level relationships. Journal of Applied Econometrics, 16(3), 289-326.

47. Pesaran, M. H. (2015). Time series and panel data econometrics. Oxford: Oxford University Press.

48. Republic of Kenya (2007). Facts and figures on health and healthrelated indicators 2006. Nairobi: Ministry of Medical Services.

49. Republic of Kenya (2007). Kenya Vision 2030: A competitive and prosperous Kenya. Nairobi: Government Printer.

50. Republic of Kenya (2008). Facts and figures on health and health related indicators 2006. Nairobi: Ministry of Medical Services.

51. Republic of Kenya (2009). Kenya National Health Accounts 2005/2006. Nairobi: Ministry of Medical Services (MOMS) and Ministry of Public Health and Sanitation (MOPHS). 
52. Republic of Kenya (2010). Public expenditure review: Policy for prosperity 2010. Nairobi: Government Printer.

53. Republic of Kenya (2012). Kenya Health Policy 2012-2030. Nairobi: Ministry of Medical Services (MOMS) and Ministry of Public Health and Sanitation (MOPHS).

54. Republic of Kenya (2013). Kenya Health Sector Strategic and Investment Plan (KHSSPI) July 2013-June 2017. Nairobi: Government Printer.

55. Republic of Kenya (2018). National and county health budget analysis 2018/19. Nairobi: Government Printer.

56. Republic of Kenya -MOH (2008). Public expenditure review 2008. Nairobi: Ministry of Health.

57. Republic of Kenya (2010). Kenya National Health accounts 2009/2010. Ministry of Medical Services (MOMS) and Ministry of Public Health and Sanitation (MOPHS).

58. Republic of Kenya (2010). The Constitution of Kenya. National Council for Law Reporting. Nairobi: Government Printer.

59. Ricci, T. F. \& Zachariadis, M. (2006). Determinants of public health outcomes: A macroeconomic perspective. Computing in Economics and Finance, Working Paper No. 107.

60. Robalino, D. A., Oscar, F.P. \& Albertus, V. (2001). Does fiscal decentralization improve health outcomes? Evidence from a cross country analysis. World Bank Working Paper Series 2565. Washington DC: World Bank.

61. Roberts, R. (2003). Poverty reduction outcomes in education and health public expenditure and aid. Working Paper No. 210. London: Center for Aid and Public Expenditure, Overseas Development Institute.

62. Schieber, G. \& Maeda, A. (1999). Health care financing and delivery in developing countries. Health Affairs, 18(3), 193-205.

63. Schultz, P.T. \& Tansel, A. (1993). Measurement of returns to adult health: Living standards measurement study. Working Paper No. 95. Washington DC: World Bank.

64. Stock, J.H., Wright, J.H. \& Yogo, M. (2002). Survey of weak instruments and weak identification in Generalized Method of Moments. Journal of Business and Economic Statistics, 20(4), 518529.

65. Stone, G.S., Tarus, T., Shikanga, M., Biwott, B., Ngetich, T., Andale, T., Cheriro, B. \& Aruasa, W. (2014). The association between insurance status and in-hospital mortality on the public medical wards of a Kenyan referral hospital. Global Health Action, 7. Available at: http://dx.doi.org/10.3402/gha.v7.23137 
66. United Nations Children's Fund (2009). Immunization Summary: A Statistical Reference Containing Data through 2007. New York: UNICEF-WHO.

67. United Nations (2015). Sustainable Development Goals (SDGs). Transforming our world. New York: United Nations.

68. United Nations Children's Fund (2019).Child mortality data. New York: UNICEF. Available at http://data.unicef.org.

69. Wagstaff, A. (2002). Inequality aversion, health inequalities and health achievement. Journal of Health Economics, 21(4), 627-641.

70. World Health Organization (2001). Macroeconomics and health: Investing in health for economic development. Geneva: WHO.

71. World Health Organization (2009). Global health observatory data repository. http://www.who.int/whosis/data/search.jsp. accessed 27-309.

72. World Health Organization (2013). Spending on health: A global overview. Fact sheet No. 319. April 2012 (2013). http://www.who.int/mediacentre/factsheets/fs319/en/ Accessed on $19 / 08 / 2013$

73. World Health Organization (2019). Trends in Maternal Mortality: 2000 to 2017. Geneva: WHO

74. World Bank (2013). Kenya Economic Update: Time to shift gears: Accelerating growth and poverty reduction in the new Kenya. World Bank. Available at http://www.worldbank.org/kenya/keu

75. Zivot, E. A. \& Andrews, D. (1992). Further evidence on the great crash, oil prices shock and the unit root hypothesis. Journal of Business and Economics Statistics, 20 (1), 25-44. 